\title{
PHYSICS
}

\section{Mass-spectra of Evaporation of Glasses in As-S System}

\section{P. Ivanitsky ${ }^{1}$, V. S. Kovtunenko ${ }^{2}$, R. O. Meshko ${ }^{1}$, M. M. Ryaboschuk ${ }^{1}$, M. V. Stoika ${ }^{3}$}

${ }^{1}$ Uzhhorod National University, 13, Kapitulna Str., t. Uzhhorod, 88000

${ }^{2}$ Cherkasy State University of technology, 460, Shevchenko Blvd, Cherkasy, 18006

${ }^{3}$ Ferenc Rakoczi II. Transcarpathian Hungarian Institute, 6, Kosuth square, Beregovo, 90200

Paper received 18.11.17; Revised 22.11.17; Accepted for publication 25.11.17.

https://doi.org/10.31174/SEND-NT2017-148V16-07

\begin{abstract}
The mass-spectra of six different compositions of As-S glasses under thermal evaporation from Knudsen cell within the temperature range of $400-520 \mathrm{~K}$ have been studied. The complicated complex nature of vapour flows of these glasses which contain about three tens of different $\mathrm{As}_{m} \mathrm{~S}_{n}$ atomic complexes $(\mathrm{m}=0-4, \mathrm{n}=0-8)$ has been revealed. By increasing the flow density of an ionizing electron beam of the mass-spectrometer the coincidence of the total mass-spectrometric composition of the vapour phase with the chemical composition of glasses before evaporation has been ensured. The presence of three types of concentration dependences for different $\mathrm{As}_{m} \mathrm{~S}_{n}$ clusters versus the chemical composition of initial glasses: growing, decreasing, dome-shaped ones has been established. The influence of technological conditions of synthesis for As-S glasses on their mass-spectra has been revealed.
\end{abstract}

Keywords: mass-spectrometry, arsenic-sulfur clusters, evaporation of chalcogenides.

Introduction. The vacuum condensation processes of As$\mathrm{S}$ amorphous films include some closely interrelated stages: evaporation of the initial material with its transfer into the vapour-gas phase; "delivery" of the vapour to the place of its deposition; condensation of vapour flow particles on the substrate surface with their chemical or physical adsorption on it; nucleation processes; growth of a new phase on the substrate. At each of these stages the determining factor for the formation of the structure and properties of the amorphous film is the atomic structure of vapour flow particles. Therefore, the main structureforming factor under condensation of As-S amorphous films is the peculiarities of mass-spectra of the vapour phase during evaporation of initial materials.

For mass-spectra of As-S glasses a considerable content of $\mathrm{As}_{m} \mathrm{~S}_{n}$ polyatomic complexes is typical, where $\mathrm{m}$ changes from zero to four, and $\mathrm{n}$ - from zero to eight [1, $2]$. These various vapour components are adsorbed on the surface of the growing film under condensation and involved into the processes of chemical self-collecting of its atomic grid. The formation of different structural and phase states of As-S amorphous films is conditioned by the chemical composition and structure of these particles, their quantitative ratios, kinetic, energy and chemical characteristics, combined with a certain set of other parameters of the condensation process. Therefore, this paper analyzes the nature of changes in mass-spectra of evaporation of As-S glasses with the change in the chemical composition of initial materials.

The analysis of mass-spectra of As-S materials, studied by different authors [3 - 9] shows that in most cases the total mass- spectrometric composition of the vapour phase does not correspond to the chemical composition of initial materials. In this case, the chemical composition of the vapour flow is generally substantially enriched with arsenic compared with the composition of initial materials (differences reach 20 at.\%). Such large deviations can be caused by several reasons: deviations from the preset chemical compositions of initial materials; differences in their structure; prolonged exposure of the substance at elevated temperatures of an effusion cell prior to the registration of the mass-spectrum, as a result of which volatile atomic particles have time to sublimate from the batch; improper conducting of mass-spectrometric measurements and processing of their results and so on. In particular, the ratio of concentrations of different vapour particles greatly differs at the initial, basic and final stages of evaporation. Therefore, our work analyzes the given problem, too.

Methodology of research. Mass- spectrometric studies were conducted by Knudsen method on МИ-1201 devices. The effusion cell was made from tantalum foil and had a small diameter of a hole equal to $0.5-0.7 \mathrm{~mm}$. Around the cell a radiation screen from tantalum foil was also placed. The ratio of the area of Knudsen cell hole to the area of its section made up 1: 200. The evaporation temperature of the cell batch was measured by the differential W-Re thermocouple. The experiments were conducted in vacuo of $\sim 10-5 \mathrm{~Pa}$, which was created by a lamellar-rotary pump Pfeiffer Vacuum DUO 2.5 and turbo-molecular pump TMH-150. The devices were calibrated according to atomic particles of aluminum vapours.

The maximum ionization efficiency of $\mathrm{As}_{m} \mathrm{~S}_{n}$ clusters is typical for exciting electrons with energies of $30-60$ $\mathrm{eV}$. That is why the flow of ionizing electrons was formed just in this energy range. The effective cross section of ionization process of various atoms and molecules by the electrons of low energies is on the average directly proportional to their sizes. The sizes of arsenic atoms are by $30 \%$ greater than those of sulfur atoms. Thus enriched with As the $\mathrm{As}_{m} \mathrm{~S}_{n}$ clusters will have much larger geometric sizes and therefore significantly greater cross sections of electron scattering. Thus, these clusters will be much more effectively ionized by the flow of exciting electrons of the mass-spectrometer and their ionic currents will prevail in experimental mass-spectra. In our opinion, just by this a significant enrichment with arsenic of the total chemical composition of the ionized flow in the massspectrometer is determined (see papers [3 - 9]). Therefore, these effects should be taken into account while obtaining reliable experimental mass-spectrometric data for evaporation of As-S materials. One way of making this effect slacken is to increase the efficiency of vapour flow ionization by an electronic gun.

To register high-quality mass-spectra the density of the vapour flow from the evaporator has to be fixed in a certain, sufficiently narrow range. Therefore, a significant increase in this parameter for growth of ionization efficiency of vapour particles is not desirable. With this aim, we significantly increased the density of the flow of ioniz- 
ing electrons in our experiments. This was achieved by two ways.

1. Tungsten cathodes of an electron gun served as the source of electrons. We replaced the cathodes of conventional V-shaped form by sharply bladed ones which thermoemitted electrons more effectively. In addition, the flow of electrons from such cathodes is focused into more subtle beams.

2. The traditional temperature of cathodes of an electron gun was increased by about $100 \mathrm{~K}$ and it reached $2100-2150 \mathrm{~K}$. As a result, the measurements showed the increase in thermoelectronic emission current from $\sim 1$ to $\sim 5 \mathrm{~mA}$. According to theoretical estimates, this corresponds to the increase in the density of the thermoelectronic emission current by 4 - 5 times more than compared to traditional conditions of mass-spectrometric studies on МИ-1201 devices. Of course, the period of functioning of the cathodes was much reduced and we replaced them for each new experiment.

For evaporation small pieces of glasses of As-S system with the chemical composition of $\mathrm{As}_{10} \mathrm{~S}_{90}, \mathrm{As}_{20} \mathrm{~S}_{80}$, $\mathrm{As}_{25} \mathrm{~S}_{75}, \mathrm{As}_{33} \mathrm{~S}_{67}, \mathrm{As}_{40} \mathrm{~S}_{60}$ та $\mathrm{As}_{44} \mathrm{~S}_{56}$ were taken. The glasses were synthesized by cooling of the ampoules with melt in cold water. The evaporation temperatures $T_{\mathrm{e}}$ of glasses of all chemical compositions were chosen to be such ones, as to ensure optimal densities of vapour flows in the mass-spectrometer. It was found that values $T_{\mathrm{e}}$, which were $30-80 \mathrm{~K}$ greater than the glass transition temperature of glasses and the same 30 - $80 \mathrm{~K}$ lower than the corresponding liquidus temperatures of As-S state diagram, correspond to such conditions. During studies the mass-spectra were recorded only during the base average period of the experiment and unstable initial and final stages of the evaporation process of glasses were not considered.

Results and their analysis. The summarized results of various mass-spectrometric studies of the vapour flow during evaporation of As-S chalcogenide glasses are given in Table 1. In the first columns of this table the average arithmetic magnitudes of the intensities of massspectra lines obtained in [3 - 9] are presented. While doing this, the averaged intensities were also normalized relative to the highest spectrum line. In the final columns of the table the mass-spectra obtained in our study are given. In addition, for comparison, in the centre of Table 1 the intensities of mass-spectra lines during evaporation of elemental sulfur are also shown. The data of Table 1 for individual atomic particles of the vapour flow have been analyzed.

\begin{tabular}{|c|c|c|c|c|c|c|c|c|c|c|c|c|}
\hline & \multicolumn{6}{|c|}{ Average arithmetic results of [3-9] } & \multicolumn{6}{|c|}{ Our results } \\
\hline & \multicolumn{12}{|c|}{ Chemical composition of evaporated glasses } \\
\hline & $\mathrm{As}_{20} \mathrm{~S}_{80}$ & $\mathrm{As}_{25} \mathrm{~S}_{75}$ & $\mathrm{As}_{33} \mathrm{~S}_{67}$ & $\mathrm{As}_{40} \mathrm{~S}_{60}$ & $\mathrm{As}_{45} \mathrm{~S}_{55}$ & $\mathrm{~S}$ & $\mathrm{As}_{10} \mathrm{~S}_{90}$ & $\mathrm{As}_{20} \mathrm{~S}_{80}$ & $\mathrm{As}_{25} \mathrm{~S}_{75}$ & $\mathrm{As}_{33} \mathrm{~S}_{67}$ & $\mathrm{As}_{40} \mathrm{~S}_{60}$ & $\mathrm{As}_{44} \mathrm{~S}_{56}$ \\
\hline \multirow[t]{3}{*}{$T_{\mathrm{e}}, \mathrm{K}$} & & & & 460 & 500 & 450 & 400 & 440 & 440 & 470 & 470 & 510 \\
\hline & \multicolumn{12}{|c|}{ The total mass- spectrometric composition of the vapour phase } \\
\hline & $\mathrm{As}_{28} \mathrm{~S}_{72}$ & $\mathrm{As}_{33} \mathrm{~S}_{67}$ & $\mathrm{As}_{34} \mathrm{~S}_{66}$ & As44 $\mathrm{S}_{56}$ & As51 $\mathrm{S}_{49}$ & $\mathrm{~S}$ & $\mathrm{As}_{11} \mathrm{~S}_{89}$ & $\mathrm{As}_{20} \mathrm{~S}_{80}$ & $\mathrm{As}_{24} \mathrm{~S}_{76}$ & $\mathrm{As}_{32} \mathrm{~S}_{68}$ & $\mathrm{As}_{42} \mathrm{~S}_{58}$ & As45 55 \\
\hline Particles & \multicolumn{12}{|c|}{ The Normalized intensities of the mass-spectrum lines for different vapour components, a.u. } \\
\hline $\mathrm{S}$ & 16 & 33 & - & - & - & - & 12 & 10 & 7 & 4 & 4 & - \\
\hline $\mathrm{S}_{2}$ & 43 & 37 & - & 15 & 10 & 1 & 41 & 39 & 25 & 23 & 17 & 6 \\
\hline As & 90 & 86 & 80 & 44 & 17 & - & 15 & 10 & 11 & 12 & 4 & 3 \\
\hline $\mathrm{S}_{3}$ & 27 & 20 & 33 & - & - & - & 39 & 27 & 17 & 8 & 5 & - \\
\hline AsS & 17 & 22 & 58 & 66 & 100 & - & 53 & 52 & 26 & 48 & 100 & 100 \\
\hline $\mathrm{S}_{4}$ & 28 & 14 & 1 & 9 & - & - & 100 & 34 & 23 & 14 & 3 & - \\
\hline $\mathrm{AsS}_{2}$ & 5 & 37 & 12 & 3 & - & - & 87 & 12 & 8 & 9 & 0 & - \\
\hline $\mathrm{As}_{2}$ & 13 & 15 & 29 & 28 & 34 & - & - & 3 & 4 & 13 & 15 & 14 \\
\hline $\mathrm{S}_{5}$ & 25 & 5 & 21 & - & - & 5 & 53 & 27 & 13 & 5 & - & - \\
\hline $\mathrm{AsS}_{3}$ & - & - & - & - & - & - & 32 & - & - & - & - & - \\
\hline $\mathrm{As}_{2} \mathrm{~S}$ & 20 & 60 & 24 & 37 & 37 & - & 0 & - & 2 & 10 & 7 & 3 \\
\hline $\mathrm{S}_{6}$ & 12 & 11 & 25 & 7 & - & 13 & 47 & 19 & 5 & 5 & - & - \\
\hline $\mathrm{As}_{2} \mathrm{~S}_{2}$ & 47 & 21 & 19 & 35 & 55 & - & - & - & - & - & 15 & 14 \\
\hline $\mathrm{S}_{7}$ & 16 & 18 & 22 & 9 & 21 & 12 & 34 & 8 & 5 & 2 & 2 & 2 \\
\hline $\mathrm{As}_{3}$ & - & 2 & 9 & - & 1 & - & - & - & - & - & 3 & - \\
\hline $\mathrm{AsS}_{5}$ & - & 3 & 28 & 1 & - & - & 12 & 4 & 6 & 8 & 5 & 2 \\
\hline $\mathrm{As}_{2} \mathrm{~S}_{3}$ & 9 & 33 & 25 & 22 & 3 & - & - & - & 5 & 25 & 28 & 6 \\
\hline $\mathrm{S}_{8}$ & 4 & 12 & 13 & 17 & 18 & 100 & 26 & 5 & 5 & - & - & - \\
\hline $\mathrm{AsS}_{6}$ & - & 4 & 17 & 5 & - & - & 7 & 6 & 7 & 9 & 7 & - \\
\hline $\mathrm{As}_{2} \mathrm{~S}_{4}$ & 33 & 35 & 18 & 34 & 19 & - & 5 & 100 & 100 & 100 & 77 & 18 \\
\hline $\mathrm{As}_{3} \mathrm{~S}_{2}$ & 1 & 13 & 12 & 24 & 16 & - & - & - & - & - & 8 & 7 \\
\hline $\mathrm{As}_{4}$ & - & - & - & - & 66 & - & - & - & - & - & 2 & 4 \\
\hline $\mathrm{As}_{2} \mathrm{~S}_{5}$ & 1 & 2 & 14 & - & - & - & - & 3 & 3 & 35 & 25 & - \\
\hline $\mathrm{As}_{3} \mathrm{~S}_{3}$ & 1 & 7 & 9 & 45 & 21 & - & - & - & - & - & 4 & 7 \\
\hline $\mathrm{As}_{3} \mathrm{~S}_{4}$ & - & - & - & 34 & 52 & - & - & - & - & 11 & 31 & 47 \\
\hline $\mathrm{As}_{4} \mathrm{~S}_{2}$ & 1 & 6 & 3 & 4 & - & - & - & - & - & 4 & 5 & - \\
\hline $\mathrm{As}_{3} \mathrm{~S}_{5}$ & - & - & - & - & - & - & - & - & - & 5 & - & - \\
\hline $\mathrm{As}_{4} \mathrm{~S}_{3}$ & 1 & 3 & 20 & 33 & 20 & - & - & - & - & - & 27 & 13 \\
\hline $\mathrm{As}_{4} \mathrm{~S}_{4}$ & 1 & 4 & 16 & 30 & 20 & - & - & - & - & - & 21 & 21 \\
\hline $\mathrm{As}_{4} \mathrm{~S}_{5}$ & - & - & - & 11 & 6 & - & - & - & - & - & 15 & 7 \\
\hline
\end{tabular}

Table 1. Mass-spectrometric data of the vapour flow during evaporation of As-S chalcogenide glasses

Clusters with high content of sulfur atoms. The main group of mass-spectra lines of As-S glasses corresponds to atomic complexes rich in sulfur. Two types of parti- cles: $S_{n}$ and $A_{s} S_{n}$, where $n=1-8$, are the most common among these complexes. These clusters are mainly present in vapour flows during evaporation of $\mathrm{As}_{x} \mathrm{~S}_{100-x}$ glasses 
rich in sulfur. We have not investigated mass-spectra of pure sulfur because it is not stable in the glassy state at room temperature. But during evaporation of various other forms of elemental sulfur within the range of temperatures $T_{e}=300 \mathrm{~K}-900 \mathrm{~K}$ the set of all atomic complexes from $S$ to $S_{8}$ is observed. The main of them are clusters $S_{2}, S_{4}, S_{6}$ та $S_{8}$. When the boiling temperature is equal to $720 \mathrm{~K}$, their ratio corresponds to $3 \%, 4 \%, 34 \%$, $59 \%$. With increasing the evaporation temperature a general pattern of growth in the vapour of a part of individual atoms and simple atomic complexes at the expense of more compound complexes is observed.

Mass-spectra of sulfur-rich glasses of As-S system obtained by us also contain all atomic complexes of $S_{n}$ from $\mathrm{S}$ to $\mathrm{S}_{8}$. But, unlike the elementary sulfur, the massspectra lines of all $S_{n}$ particles are quite intense and lie in the range from 10 to $100 \mathrm{a}$. u. At this, for the composition of $\mathrm{As}_{10} \mathrm{~S}_{90}$ glasses the most intense mass-spectrum line corresponds to the particle $\mathrm{S}_{4}$. With the growth of arsenic part in the composition of glasses the intensities of these lines naturally reduce gradually and for As-rich samples in the vapour phase a small quantity of only $S_{2}$, $\mathrm{S}_{3}$ та $\mathrm{S}_{7}$ particles appears.

The averaged data of other researchers correlate quite well with our results. But there are a few features in them that are difficult to explain. 1 . The concentration of all $S_{n}$ complexes changes nonmonotonously with changing the chemical composition of glasses. 2. The intensity of lines of $\mathrm{S}_{7}$ clusters is practically identical for all investigated glasses from $\mathrm{As}_{20} \mathrm{~S}_{80}$ to $\mathrm{As}_{45} \mathrm{~S}_{55}$, the concentration of sulfur atoms of which is reduced more than twice. 3. The intensity of $\mathrm{S}_{8}$ cluster lines even increases by four times at the indicated changes in the chemical composition of glasses.

Quite a different behavior with changing the chemical composition of evaporated glasses is typical for $\mathrm{AsS}_{\mathrm{n}}$ particles of the second type. In particular, $\mathrm{AsS}_{3}$ and $\mathrm{AsS}_{4}$ complexes have not been reported in most previous studies on evaporation processes of $\mathrm{As}_{x} \mathrm{~S}_{100-x}$ glasses. In our own experiments only $\mathrm{AsS}_{3}$ particles were fixed in the vapour phase during evaporation of $\mathrm{As}_{10} \mathrm{~S}_{90}$ glasses exclusively.

Our experiments also revealed $\mathrm{As}_{2} \mathrm{~S}_{5}$ clusters in vapour flows of glasses with $20 \leq \mathrm{x} \leq 40$ at.\%. Especially intense lines of these particles are seen in mass-spectra of $\mathrm{As}_{33} \mathrm{~S}_{67}$ and $\mathrm{As}_{40} \mathrm{~S}_{60}$ glasses. In contrast to our data, previous studies by other authors found such complexes mainly in vapours of glasses only in the vicinity of $\mathrm{As}_{33} \mathrm{~S}_{67}$ compositions.

It should be noted that in mass-spectra of vapour flows of $\mathrm{As}_{33} \mathrm{~S}_{67}$ glasses we also constantly recorded a weak line $\left(\sim 5\right.$ a. u.) of $\mathrm{As}_{3} \mathrm{~S}_{5}$ atomic particles. In all other studies this particle was not detected.

Clusters with commensurable content of arsenic and sulfur atoms. Quite a large number of mass-spectra lines of $\mathrm{As}_{x} \mathrm{~S}_{100-x}$ glasses corresponds to the complexes in which quantities of sulfur and arsenic atoms are equal or differ by one. One of such AsS clusters is the second main part of vapour flows of the investigated glasses. The intensity of lines of this cluster is high for all glasses and it is maximum for mass-spectra of glasses with a high content of arsenic both for our experiments and other articles.

According to our data the concentration of $\mathrm{AsS}_{2}$ complexes is high enough only for vapours of $\mathrm{As}_{10} \mathrm{~S}_{90}$ glasses (the line intensity is 87 a. u.). With the growth of As content in glasses the number of clusters is rapidly declining and they are already absent for samples with $\mathrm{x} \geq 40$ at. $\%$. According to other researchers $\mathrm{AsS}_{2}$ atomic particles significantly contribute only into mass-spectra of $\mathrm{As}_{33} \mathrm{~S}_{67}$ glasses.

In previous papers in mass - spectra of almost all glasses of As-S systems there were recorded quite noticeable lines of $\mathrm{As}_{2} \mathrm{~S}, \mathrm{As}_{2} \mathrm{~S}_{2}$ and $\mathrm{As}_{2} \mathrm{~S}_{3}$ clusters (the intensity of lines was within the limits from 10 to 60 a. u.). But our research revealed such clusters only in vapour flows of glasses rich in arsenic (mainly for compositions with $x \geq 33$ at.\%.). The intensities of lines of the given particles in our mass- spectra are much smaller (2 - 25 a. u.).

Quite unexpected are the averaged results of previous research as to the content of $\mathrm{As}_{x} \mathrm{~S}_{100-x}$ clusters with a large number of arsenic atoms: $\mathrm{As}_{3} \mathrm{~S}_{2} . \mathrm{As}_{3} \mathrm{~S}_{3} . \mathrm{As}_{4} \mathrm{~S}_{3}$ and $\mathrm{As}_{4} \mathrm{~S}_{4}$ in the vapours. These atomic particles were found in the samples of all chemical compositions, beginning with $\mathrm{As}_{20} \mathrm{~S}_{80}$. The intensities of their lines in mass-spectra naturally grow with the increase of $\mathrm{x}$, beginning from $1 \mathrm{a}$. u. and reaching 20 - 40 a. u. In our experiments such clusters are found in vapours of glasses only for $\mathrm{x} \geq 40$ at.\%. At this the concentrations of $\mathrm{As}_{4} \mathrm{~S}_{3}$ and $\mathrm{As}_{4} \mathrm{~S}_{4}$ clusters are commensurable with the data from previous studies, and the concentrations of $\mathrm{As}_{3} \mathrm{~S}_{2}$ and $\mathrm{As}_{3} \mathrm{~S}_{3}$ clusters are almost by an order of magnitude less in comparison with them.

Clusters with high content of arsenic atoms. Atomic particles with a large number of As atoms in vapours of As-S system are mainly presented near $\mathrm{As}_{\mathrm{n}}$, where $\mathrm{n}$ varies from 1 to 4 . But only As and $\mathrm{As}_{2}$ lines have significant intensities in mass-spectra. In previous studies a great decrease in the intensity of As lines (from 90 to 17 a. u.) with increasing the arsenic concentration in glasses (from 20 to 45 at.\%) is unclear. However, in our experiments, the intensities of As lines in mass-spectra of glasses with the same range of compositions are much lower and change very little within 3-10 a. u. Researchers usually indicate [1 - 3], that lines of single arsenic atoms in mass-spectra of As-S glasses appear largely due to dissociation of AsS particles under the influence of an ionizing electron beam. But in this case, mass- spectra must have the appropriate intensity of lines of single sulfur atoms. Moreover, the intensities of $\mathrm{f} \mathrm{S}$, As and AsS lines should correlate with each other, which is not observed in the mass-spectra presented by previous researchers.

At the same time, these distinct patterns of lines are typical for the lines of these particles in our mass-spectra of all As-S glasses. In particular, the intensities of sulfur and arsenic lines in them are very close, and the intensities of AsS lines by 5-10 times higher than S and As lines. In addition, a strong increase in the intensity of AsS lines (to 100 a. u.) for the glasses with $x \geq 40$ at.\% is accompanied by the decrease in the intensity of As and $\mathrm{S}$ lines to $\sim 3 \mathrm{a}$. $\mathrm{u}$. This indicates to the fact that if dissociation of AsS dimers does occur when the ionization of ionic flow takes place, it does not play a significant role in our experiments.

Close are the results of all studies as to availability of $\mathrm{As}_{4}$ and $\mathrm{As}_{4} \mathrm{~S}_{2}$ clusters in vapour flows of As- S materials. At this the lines of As 4 particles are clearly revealed only in mass-spectra of glasses with the compositions in the vicinity of $\mathrm{As}_{44} \mathrm{~S}_{56}$. However, in our studies, the intensity of these lines was at the level of $2-4$ a. u., whereas in previous studies it exceeded $60 \mathrm{a}$. u. 
$\mathrm{As}_{4} \mathrm{~S}_{2}$ clusters are present in vapours of all investigated $\mathrm{As}_{x} \mathrm{~S}_{100-x}$ glasses of compositions with $33 \leq \mathrm{x} \leq 40$ at. $\%$ (with intensity of lines from 3 to 5 a. u.). But in previous studies a significant concentration of such atomic particles was also revealed in the glasses rich in sulfur (the range of $\mathrm{x}$ is from 20 to 25 at. $\%$ ).

Table. 1 also shows a comparison of the initial chemical composition of glasses before evaporation and the total chemical composition of the vapour flow. As follows from these data, for many previous experiments [3 - 9] the total mass-spectrometric composition of the vapour phase of glasses does not correspond to the chemical composition of initial materials. This averaged vapour flow contains $4-8$ at.\% of arsenic atoms more than compared with the initial glasses. Exceptions are only $\mathrm{As}_{33} \mathrm{~S}_{67}$ glasses, for which such deviation does not exceed 1 at.\% (see Table 1). Unfortunately, the authors of papers indicated above do not give a detailed description of mass-spectrometric experiments by which one could analyze the detected deviations. In our massspectrometric studies within the experimental error the total mass-spectrometric composition of the vapour phase coincides with the chemical composition of glasses before evaporation.

It should also be noted that mass-spectra of As-S glasses under evaporation rather strongly vary depending on the preparation conditions of the initial material. This is evidenced by the experimental data obtained both by us and other researchers $[1,2]$. However, in all these spectra relatively "stable" vapour particles appear whose parts in mass-spectra are little dependent on the conditions of synthesis of the initial material. These include $\mathrm{S}, \mathrm{S}_{2}, \mathrm{~S}_{3}$, $\mathrm{As}_{2} \mathrm{~S}_{3}, \mathrm{AsS}_{5}, \mathrm{AsS}_{6}, \mathrm{As}_{2} \mathrm{~S}_{4}, \mathrm{As}_{3} \mathrm{~S}_{4}, \mathrm{As}_{4} \mathrm{~S}_{4}$ clusters. At the same time, the parts of many atomic complexes vary greatly during the transition from one sample of glasses to another. Among them are $\mathrm{AsS}, \mathrm{As}_{2}, \mathrm{As}_{2} \mathrm{~S}, \mathrm{~S}_{7}, \mathrm{~S}_{8}, \mathrm{As}_{3} \mathrm{~S}_{2}$, $\mathrm{As}_{4} \mathrm{~S}_{2}, \mathrm{As}_{4} \mathrm{~S}_{3}$.

The analyzed mass-spectra of As-S glasses are prepared at evaporation temperatures of initial materials from 400 to $600 \mathrm{~K}$, which are by $\sim 80 \mathrm{~K}$ lower than the melting temperature of appropriate substances. In actual manufacturing condensation processes of amorphous films the evaporation of initial materials is carried out at higher temperatures of the evaporator $(500-900 \mathrm{~K})$. It is clear that in such circumstances of evaporation massspectra of glasses can sufficiently differ from the considered above. But methodically to investigate them by traditional mass-spectrometry methods is much more difficult.

Conclusions. The results of mass-spectrometric studies of evaporation processes of As-S glasses within the range of chemical compositions from $\mathrm{As}_{10} \mathrm{~S}_{90}$ to $\mathrm{As}_{44} \mathrm{~S}_{56}$ have been analyzed. It has been revealed that mass- spectra of vapour flows of these glasses have a complicated complex character and contain about three tens of different atomic complexes. But the total mass-spectrometric composition of the vapour phase in the majority of mass-spectroscopic studies does not correspond to the chemical composition of initial materials and is significantly rich in arsenic atoms. This fact is explained by the dependence of the ionization probability of vapour particles by an electron beam of the mass-spectrometer on the size of these particles. With significant increase in the flow density of ionizing electrons the ionization probabilities of different vapour clusters are aligned. Under such circumstances within the experimental error the total mass-spectrometric composition of the vapour phase of As-S glasses coincides with the chemical composition of glasses before evaporation.

The dependences of concentrations of different $\mathrm{As}_{m} \mathrm{~S}_{n}$ clusters in the vapour flow on the chemical composition of initial $\mathrm{As}_{x} \mathrm{~S}_{100-x}$ glasses have been studied. The presence of clear correlations in the behavior of these two parameters has been established. Three types of dependencies have been revealed: a) the concentration of some vapour particles decreases with the growth of $x$; b) the concentration of other particles increases in this case; c) the dependence of concentration of some vapour particles on the parameter $\mathrm{x}$ has a dome-like shape.

It has been found that the change in the structural state of initial As-S glasses by changing the technological conditions of their synthesis can cause significant changes in the concentrations of various complexes in massspectra.
1. Popescu A. Structure modelling of chalcogenide vitreous films by computational chemistry program // Moldavian J. of physical sciences. 2002. №2.

2. A. Popescu, D. Savastru, M. Ciobanu, S. Miclos, V. T. Dolghier, J. Optoel. Adv. Mater. 13, 1193 (2011).

3. Martin T.P. Arsenic sulfide clusters // Solid state commun. 1983. - V.47, №2. - P.111-114.

4. Chern G.C., Zauks J., McGhie A.R. Spin-coated amorphous chalcogenide films: thermal properties // J. Applied Physics. 1983. - V.54. - №8. - P. 4596-4601.

5. K. White., B. Kumar., K.Rai Amarendra, Effect of deposition rate on structure and properties of As2S3 films, Thin Solid Films. 161, 139 (1988)

6. A.S. Pashynkyn, A.D. Molodik, V.I. Belousov, S.S.

\section{ENCES}

Strelchenko, V.L. Fedorov, Steam Composition As2S3, Izv. USSR Academy of Sciences. Neorhanycheskye materials. 16, 1600 (1974).

7. L. Gutzov, I. Avramov, On the mechanism of formation of amorphous condensates from the vapour phase (I). General theory, J. Non-Cryst. Sol. 16, 128 (1974).

8. A.J. Leadbetter, A.J. Apling, M.F. Daniel, Structure of vapour-deposited amorphous films of arsenic chalcogenides, J. Non-Cryst. Sol. 21, 47 (1976).

9. A.V. Dalekorey, Sh.Sh. Demesh, V.S. Kovtunenko, R.O. Meshko, Mass-spectra of Steam Streams During Evaporation of As-S System, Scientific herald of Uzgorod state university: physics. N31, 79 (2012).

\section{Мас-спектры испарения стекол системы As-S}

\section{В. П. Иваницкий, В. С. Ковтуненко, В. С. Мешко, М. М. Рябощук, М. В. Стойка}

Аннотация. Исследованы масс-спектры шести различных составов стекол системы As-S при термическом испарении с ячейки Кнудсена в диапазоне температур 400-520 К. Обнаружен сложный комплексный характер паровых потоков данных стекол, которые содержат около трех десятков различных атомных комплексов $\mathrm{As}_{m} \mathrm{~S}_{n}(m=0-4, n=0-8)$. Повышением плотности потока ионизирующего электронного пучка масс-спектрометра обеспечено совпадение суммарного массспектрометрического состава паровой фазы с химическим составом стекол до испарения. Установлено наличие трех типов зависимостей концентраций различных кластеров $\mathrm{As}_{m} \mathrm{~S}_{n}$ от химического состава исходных стекол: растущих, спадающих и куполообразных. Выявлено влияние технологических условий синтеза стекол As-S на их масс-спектры.

Ключевые слова: масс-спектрометрия, мышьяк-сера кластеры, испарение халькогенидов. 